University of Wollongong

Research Online

Faculty of Engineering - Papers (Archive)

Faculty of Engineering and Information

Sciences

$1-1-2012$

\title{
Use of the soil modulus for compaction control of compacted soils
}

Ana Heitor

University of Wollongong, aheitor@uow.edu.au

Buddhima Indraratna

University of Wollongong, indra@uow.edu.au

Cholachat Rujikiatkamjorn

University of Wollongong, cholacha@uow.edu.au

Follow this and additional works at: https://ro.uow.edu.au/engpapers

Part of the Engineering Commons

https://ro.uow.edu.au/engpapers/5196

\section{Recommended Citation}

Heitor, Ana; Indraratna, Buddhima; and Rujikiatkamjorn, Cholachat: Use of the soil modulus for compaction control of compacted soils 2012, 1083-1088.

https://ro.uow.edu.au/engpapers/5196

Research Online is the open access institutional repository for the University of Wollongong. For further information contact the UOW Library: research-pubs@uow.edu.au 


\title{
USE OF THE SOIL MODULUS FOR COMPACTION CONTROL OF COMPACTED SOILS
}

\author{
A. Heitor ${ }^{a}$, B. Indraratna ${ }^{b}$ and C. Rujikiatkamjorn ${ }^{c}$ \\ Centre for Geomechanics and Railway Engineering, University of Wollongong, \\ Wollongong NSW 2500, Australia. E-mail: ${ }^{a}$ aprh838@uowmail.edu.au, \\ bindra@uow.edu.au, ${ }^{c}$ cholachat@uow.edu.au
}

\begin{abstract}
Insufficient compaction conditions can cause significant roadway infrastructure maintenance costs. Conventional compaction control, using nuclear methods, is based on the discrete in situ determination of the dry density and moisture content. Recently, there has been an increase interest in alternative methods for compaction control using intelligent compaction technologies. This method enables the continuous measurement of the soil modulus and the degree of compaction on the layer that is being compacted. Thus, the efficiency of the compaction process can be maximized. Although the adoption of this method is very promising, it constitutes a change of project specification for the contractors (i.e. use of the soil modulus instead of the dry unit weight). Furthermore, the role of dry unit weight, moisture content and matric suction on the soil modulus is still not well understood. This paper presents a review study of the effect of soil types, prepared under standard the same Proctor compaction energy, on the small-strain shear modulus. The results suggest that there seems to be a close relationship between the fines content and small strain shear modulus on the dry side of the optimum, whereas, its effect seems less evident on the wet side of the optimum.
\end{abstract}

Keywords: Matric suction, Intelligent compaction control, Soil modulus.

\section{INTRODUCTION}

During construction, the field compaction characteristics are evaluated based on a minimum deviation interval from the pre-established laboratory key parameters (i.e. maximum dry density (MDD) and optimum moisture content (OMC), .AS 3798-2007). Although controlling the quality of compaction with those criteria has been well established, problems related to poor compaction still occur. This, in turn, often deems necessary the execution of costly and time consuming post-construction maintenance because the verification of compaction control is discrete and covers a limited area (typically less than less than $1 \%$ of the actual compacted area .NCHRP, 2005).

In addition, field compaction using conventional rollers (i.e. with static and vibratory drums) may not provide uniform compaction due to the differences in hydration time and lift thickness. These variations can have substantial effects on the stress-strain behavior of the compacted soil (Seed and Chan, 1959). Recently, intelligent compaction control (ICC) technologies have emerged to address these problems. Various manufacturers have

Proceedings of the International Conference on Ground Improvement and Ground Control

Edited by Buddhima Indraratna, Cholachat Rujikiatkamjorn and Jayan S. Vinod

Copyright $@ 2012$ by Research Publishing Services. All rights reserved.

ISBN: 978-981-07-1896-1 :: doi:10.3850/978-981-07-1896-1_04-0408 
equipped their compaction roller drums with an accelerometer based measuring systems (i.e. vibratory rollers), which are able to record the soil response (i.e. soil stiffness or modulus) while the soil is being compacted. The wide application of ICC technology in the compaction of fills seems very promising; however, the effects of dry unit weight, moisture content, matric suction, and the imparted energy on the soil modulus are not understood very well, particularly in cohesive soils. Undoubtedly these parameters have a strong influence on the soil modulus, particularly the matric suction (Sawangsuriya et al., 2008).

This paper examines the effect of moisture content, dry unit weight, and matric suction on the dynamic properties of different types of compacted soils, namely the small strain shear modulus. The effect of the fines content on the matric suction and on the small strain stiffness is also evaluated.

\section{SOIL PROPERTIES AND METHODS}

\subsection{Soil Type and Methodology}

The study included the analysis of eight different fine-grained soils whose modulus, compaction parameters and matric suction were reported in various literatures. The different soils, their respective reference along with their main properties are listed in Table 1. All tests specimens reported were compacted using equivalent Proctor compaction energy $\left(\approx 500 \mathrm{~kJ} \cdot \mathrm{m} / \mathrm{m}^{3}\right)$. The compaction curves obtained for the Soils 1 to 6 are shown in Figure 1. Note that for Soils 7 and 8 only the conditions at OMC were reported.

The shear wave velocity was measured using Bender elements and plate element velocity transducers whereas matric suction was evaluated using filter paper method, tensiometer, thermal dissipation sensor and psychrometers. The experimental set-ups details as well as the methodology adopted for the travel time determination can be found in the respective references (Claria Jr. and Rinaldi, 2007; Sawangsuriya et al., 2008; Indraratna et al., 2012; Rujikiatkamjorn et al., 2012; Inci et al., 2003).

Table 1. Main properties of the soils considered.

\begin{tabular}{|c|c|c|c|c|c|c|c|c|c|c|c|}
\hline & $\begin{array}{c}\text { Soil } \\
\text { type } \\
\text { USGS }^{\text {a }}\end{array}$ & $\begin{array}{l}\text { LL } \\
(\%)\end{array}$ & $\begin{array}{l}\text { PI } \\
(\%)\end{array}$ & $G_{S}$ & $\begin{array}{c}\text { Sand } \\
(\%)\end{array}$ & $\begin{array}{l}\text { Silt } \\
(\%)\end{array}$ & $\begin{array}{l}\text { Clay } \\
(\%)\end{array}$ & $\begin{array}{l}\mathrm{FC} \\
(\%)\end{array}$ & $\begin{array}{c}\mathrm{OMC} \\
(\%)\end{array}$ & $\begin{array}{c}\mathrm{MDD} \\
\left(\mathrm{kN} / \mathrm{m}^{3}\right)\end{array}$ & Reference \\
\hline 1 & CL & 21 & 15 & 2.63 & 45 & 45 & 10 & 55 & 15.5 & 17.7 & $\begin{array}{l}\text { Rujikiatkamjorn } \\
\text { et al., } 2012\end{array}$ \\
\hline 2 & SP-SC & 25 & 10 & 2.7 & 89 & 7 & 4 & 11 & 12.1 & 19 & $\begin{array}{l}\text { Indraratna } \\
\text { et al., } 2012\end{array}$ \\
\hline 3 & ML & 25.2 & 3.4 & 2.69 & 2 & 80 & 18 & 98 & 20.8 & 15.4 & $\begin{array}{l}\text { Claria Jr and } \\
\text { Rinaldi, } 2007\end{array}$ \\
\hline 4 & SC & 28 & 14 & 2.7 & 59 & 23 & 18 & 41 & 13.5 & 18.5 & Sawangsuriya \\
\hline 5 & ML & 28 & 11 & 2.69 & 11.9 & 82.4 & 5.7 & 88.1 & 13.5 & 17.9 & et al., 2008 \\
\hline 6 & $C L$ & 42 & 24 & 2.73 & 8.9 & 63.8 & 27.1 & 91.1 & 22 & 15.8 & \\
\hline 7 & $\mathrm{SC}$ & 16 & 7 & 2.68 & 56 & 27 & 17 & 44 & 9 & 20.5 & Inci et al., \\
\hline 8 & CL & 40 & 17 & 2.68 & 3 & 38 & 59 & 97 & 22 & 15.9 & 2003 \\
\hline
\end{tabular}

Note: $\mathrm{LL}=$ liquid limit; $\mathrm{PI}=$ plasticity index; $\mathrm{G}_{s}=$ specific gravity; $\mathrm{FC}=$ fines content $(<0.075 \mathrm{~mm})$; $\mathrm{OMC}=$ optimum moisture content; $\mathrm{MDD}=$ maximum dry density

${ }^{a}$ Letters in classification refer to Unified Soil Classification System (USGS). 


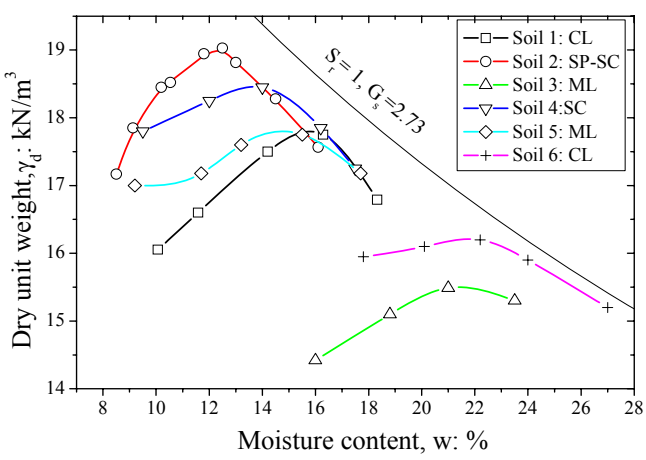

Figure 1. Compaction data for the Soils 1 to 6 .

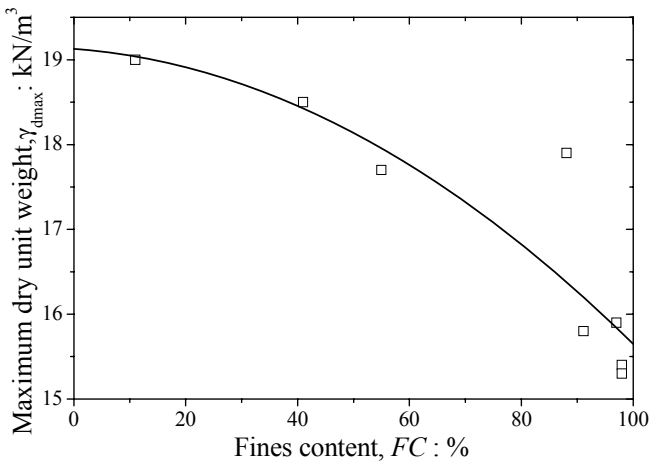

Figure 2. Variation of maximum dry unit weight with the percentage of fines content.

\section{RESULTS AND DISCUSSION}

\subsection{Compaction Characteristics}

The compaction curves of the Soils 1 to 6 presented in Figure 1, show that soils with higher plasticity exhibit smaller dry unit weight and higher optimum moisture content than those with lower plasticity. For the same compaction energy (i.e. Standard Proctor) Soil 2 has the highest dry unit weight while soil 3 has the smallest dry unit weight. Although Soils 4 and 5 are low plasticity soils $(\mathrm{PI}<15 \%)$ and have approximately the same optimum moisture content, the Soil 4 can be compacted at a higher dry unit weight than that of Soil 5 . This is likely to be related with the fact that the fines content percentage in the Soil 5 is much larger. This observation is consistent with the common assumption that the optimum moisture is strongly associated with state index properties such as the Atterberg plastic limit (Sivrikaya et al., 2008). The maximum dry unit weight variation with the fines content percentage is plotted in Figure 2. The MDD seems to be inversely proportional to the fine content percentage, that is, as the fine content increases the MDD decreases. This suggests that MDD is not only associated with the state index properties but also with the present amount of the fine fraction.

\subsection{Matric Suction}

The as-compacted matric suction values obtained for Soils 1 to 6 are given in Figure 3. Overall, the matric suction decreased as the moisture content increased for all soils. The soils with larger percentage of fines content exhibited the larger matric suction values. For moisture content in the range of $18 \%<w<22 \%$, however, Soil 3 with the highest fine content showed smaller matric suction values compared to Soil 6. Although Soil 6 had a lower fine content than that of Soil 3, a larger percentage of those fines were composed of clay size particles, $27 \%$ and $18 \%$ respectively. This result can be explained on the basis of the interaction between solid grains-meniscus water and air in the soil. According to Fisher (1926) the magnitude of the contact force $P$ for different suction levels is directly proportional to the particle radius $R$ (Figure 4). This suggests that the magnitude of matric suction is intrinsically associated with the nominal particle size. 


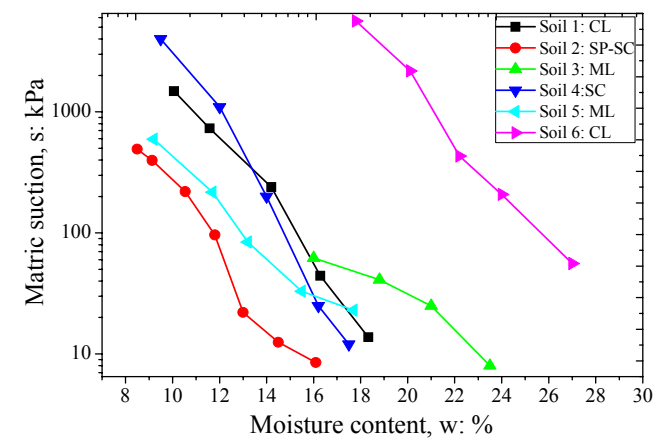

Figure 3. As-compacted matric suctionmoisture content relationship.

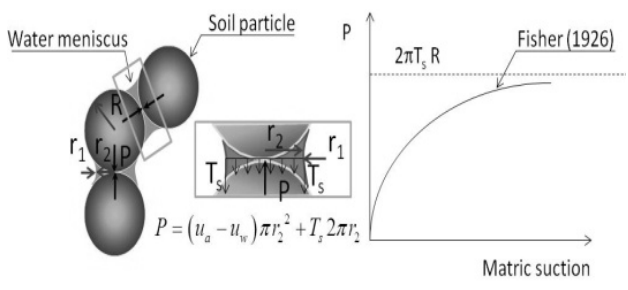

Figure 4. Water-air menisci between two spheres with the induced contact force $P$ versus matric suction (adapted from Fisher, 1926).
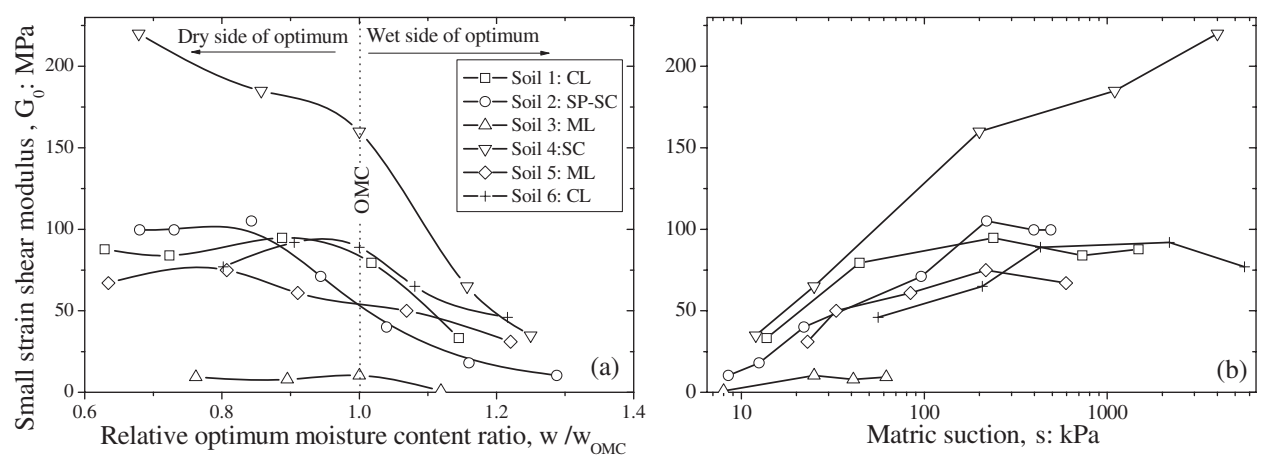

Figure 5. Variations of $G_{0}$ with (a) relative moisture content ratio and (b) matric suction.

\subsection{Small Strain Modulus}

The variations of the small strain shear modulus $\left(G_{0}\right)$ with relative optimum moisture content ratio and matric suction are shown in Figures 5(a) and (b), respectively. The relative optimum moisture content ratio $\left(w / w_{\text {OMC }}\right)$ is used to facilitate the comparison between the different soils and represents the ratio between the compacted moisture content over the reference OMC. Overall, $G_{0}$ decreases as moisture content increases and matric suction decreases. Note that, the maximum $G_{0}$ did not have a distinguished relationship with the maximum dry unit weight for all soils mentioned in this paper. In fact, on the dry side of OMC $\left(w / w_{\mathrm{OMC}}<1\right) G_{0}$ remains in a similar order of values whereas on the wet side of OMC $\left(w / w_{\text {OMC }}>1\right) G_{0}$ decreases as moisture content increases. Although this behaviour might not be considered intuitive at first sight, it can be attributed to the increase in dry unit weight inter-related to the decrease in matric suction together with the corresponding change in the soil structure (Delage et al., 1996). These observations were consistent for the majority of the cases indicating that $G_{0}$ behaviour may be relatively independent of the soil type or fines content. 


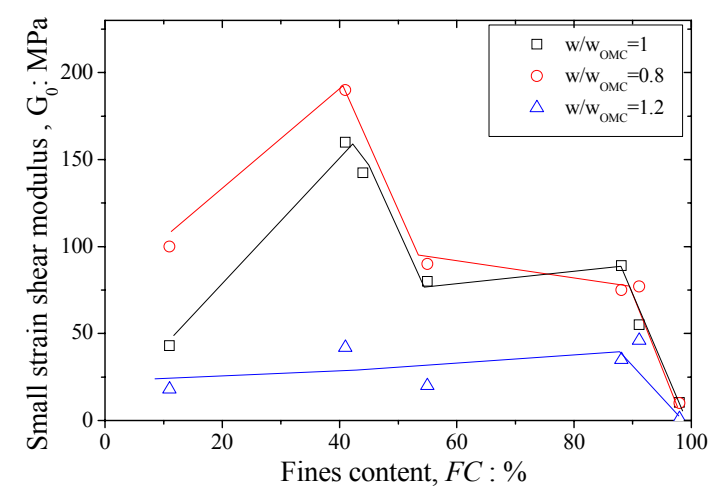

Figure 6. Variations of $G_{0}$ with fines content at different $w / w_{\mathrm{OMC}}$.

Figure 6 shows the variation of $G_{0}$ with fines content at $\mathrm{OMC}$, at 0.8 and $1.2 \mathrm{of} w / w_{O M C}$, which are on the dry side and wet side of OMC, respectively. It is apparent that a reduction of the fines content leads to the $G_{0}$ increase on the dry side of OMC and at OMC. This indicates that in spite of matric suction controlling the state of stress that governs the mechanical properties (i.e. shear modulus) of unsaturated soils, the dry unit weight magnitude is far more significant to the $G_{0}$ behaviour. In other words, the soils with the highest fine content percentage exhibited the larger values of matric suction (see Figure 3 ) but also the lowest values of dry unit weight (see Figure 2). This is clearly illustrated in the OMC data from Soil $4\left(F C=41 \%, s=200 \mathrm{kPa}, \mathrm{MDD}=18.5 \mathrm{kN} / \mathrm{m}^{3}\right)$ and Soil $6(F C=91 \%$, $s=430 \mathrm{kPa}, \mathrm{MDD}=15.8 \mathrm{kN} / \mathrm{m}^{3}$ ) which yielded a $G_{0}$ of $89 \mathrm{MPa}$ and $160 \mathrm{MPa}$, respectively (see Figures 3 and 5). Conversely, on the wet side of OMC this effect is not evident. In fact, $G_{0}$ seems to be relatively independent of the fine content. Similar observations were also obtained by Sawangsuriya et al., 2008).

\section{CONCLUSIONS}

From the comparison of compaction characteristics of different soil types, it was found that the maximum dry unit weight increased when the fines content decreased.

This study also revealed that matric suction-moisture content of specimens belonging to different types of soils can be directly related with their respective fine content, particularly the relative percentage of the clay size particles. The small strain behaviour of different soils was consistent in most cases. Generally, $G_{0}$ remains in a similar order of values on the dry side of OMC whereas on the wet side of OMC it decreases as moisture content increases. This suggests that under a modulus-based compaction control perspective, the exclusive use of a reference soil modulus may lead to compaction states that do not satisfy the conventional compaction control dry unit weight criteria (i.e. 95\% MDD). A surveillance of field moisture may be required in order to avoid unwanted low dry unit weights. Although no clear relationship could be established between the $G_{0}$ and fines content, it was observed that $G_{0}$ increased as the fines content decreased on the dry side of OMC and at OMC. Conversely, on the wet side, this effect is less evident. Further corrections of $G_{0}$ for larger strain range are needed for field assessment of ICC compaction efficiency because 
the strains developed during vibratory roller compaction are expected to be larger, and the modulus of the soil expected to be smaller.

\section{ACKNOWLEDGMENTS}

The authors acknowledge the financial assistance provided by the Australia Research Council (Australia), Penrith Lakes Development Corporation and Coffey Geotechnics.

\section{REFERENCES}

1. Claria Jr, J. J. and Rinaldi, V. A. (2007). Shear wave velocity of a compacted clayey silt. Geotechnical Testing Journal 30(5): 399-408.

2. Delage, P., Audiguier, M., Cui, Y. J. and Howat, M. D. (1996). Microstructure of a Compacted Silt. Canadian Geotechnical Journal 33: 150-158.

3. Fisher, R. A. (1926). On the capillary forces in an ideal soil; correction of formulae given by W. B. Haines. The Journal of Agricultural Science 16: 492-505.

4. Inci, G., Yesiller, N. and Kagawa, T. (2003). Experimental investigation of dynamic response of compacted clayey soils. Geotechnical Testing Journal 26(2): 125-141.

5. Indraratna, B., Heitor, A. and Rujikiatkamjorn, C. (2012). The effect of dry unit weight, suction, and imparted energy on the modulus of a compacted mixture of silty sand. 5th Asia-Pacific Conference on Unsaturated Soils. Pattaya, Thailand: (in press).

6. NCHRP (2005). Intelligent Soil Compaction Systems. Transportation Research board: TRB report 676, National Cooperative Highway Research Program: 165.

7. Rujikiatkamjorn, C., Heitor, A. and Indraratna, B. (2012). The effect of dry unit weight, suction, and imparted energy on the modulus of a compacted mixture of sand and kaolin $2^{\text {nd }}$ International Conference in Transportation Geotechnics. Hokkaido, Taylor and Francis: (Submitted).

8. Sawangsuriya, A., Edil, T. B. and Bosscher, P. J. (2008). Modulus-suction-moisture relationship for compacted soils. Canadian Geotechnical Journal 45(7): 973-983.

9. Seed, B. and Chan, C. K. (1959). Compacted clays: Structure and strength characteristics. Journal of soil mechanics and Foundations division Transactions 126(Part I): 1344-1380.

10. Sivrikaya, O., Togrol, E. and Kayadelen, C. (2008). Estimating compaction behavior of fine-grained soils based on compaction energy. Canadian Geotechnical Journal 45(6): 877-887.

11. Standards Australia (2007) Guidelines on earthworks for commercial and residential developments. Australian Standard AS 3798. Sydney. 